\title{
MAP SHOWING APPROXIMATE GROUND-WATER CONDITIONS IN THE PARKER QUADRANGLE, ARAPAHOE AND DOUGLAS COUNTIES, COLORADO
}

By

John O. Maberry and Eugene R. Hampton

FOLIO OF THE

PARKER QUADRANGLE, COLORADO

MAP I-770-K

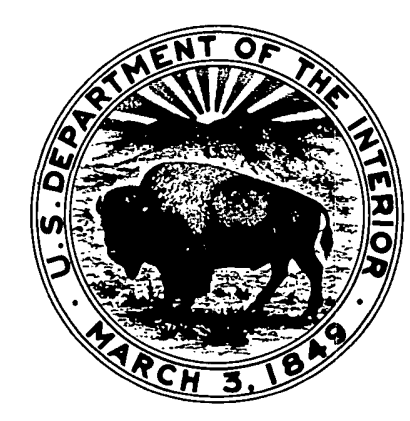

PUBLISHED BY THE U.S. GEOLOGICAL SURVEY 